\title{
The Ability and Willingness Paradox in Family Firm Innovation*
}

\author{
James J. Chrisman \\ Mississippi State University \\ Mississippi State, MS 39762-9581 \\ Tel: 662-325-1991 \\ Email: jchrisman@businessmsstate.edu \\ and \\ Centre for Entrepreneurship and Family Enterprise \\ University of Alberta, Canada \\ Jess H. Chua \\ Haskayne School of Business \\ University of Calgary \\ Calgary, Alberta T2N 1N4, Canada \\ Tel: 403-220-6331 \\ Email: chua@ucalgary.ca \\ and \\ Centre for Family Business \\ IEED, Lancaster University Management School, UK
}

\author{
Alfredo De Massis \\ (corresponding author) \\ Center for Family Business \\ IEED, Lancaster University Management School \\ Bailrigg, Lancaster, LA1 4YX, UK \\ Tel: +44 (0)1524 594057 \\ Email: a.demassis@lancaster.ac.uk \\ Federico Frattini \\ Politecnico di Milano \\ Dipartimento di Ingegneria Gestionale \\ Via Lambruschini 4B (Building 26/B) \\ 20156 Milan, Italy \\ Tel: +390223992796 \\ Email: federico.frattini@polimi.it

\section{Mike Wright} \\ Centre for Management Buyout Research \\ and Entrepreneurship Research Centre \\ Imperial College Business School \\ Exhibition Road \\ London, SW7 2AZ, UK \\ Tel: +44-7725-159-873 \\ Email: mike.wright@imperial.ac.uk \\ and \\ University of Ghent, Belgium
}

* Authors' names listed in alphabetical order, with all authors having contributed equally.

Running title: Family Firm Innovation Future Agenda 


\title{
The Ability and Willingness Paradox in Family Firm Innovation
}

\begin{abstract}
We present a framework of how family involvement influences innovation management based on ability (discretion to act) and willingness (disposition to act), two drivers that distinguish family firms from non-family firms and lead to heterogeneity among family firms. Paradoxically, family firms have superior ability yet lower willingness to engage in technological innovation. Resolving this paradox should yield new insights about innovation management in general. We summarize and position the papers in this special issue according to these drivers and set out an agenda for further research that will contribute to a better understanding of family firms' heterogeneous and paradoxical behaviors.
\end{abstract}

\section{Introduction}

Owing to the importance of innovation for economic growth and the ubiquity of the family form of governance (La Porta et al., 1999; Villalonga and Amit, 2009), scholars are paying increasing attention to innovation management in family firms (De Massis et al., 2013a, 2013b; Kellermanns et al., 2012; Chrisman and Patel, 2012; Patel and Chrisman, 2014). Innovation management in family firms is also inherently interesting because there are strong theoretical reasons to believe that it differs from innovation management in non-family firms. For example, family governance has been found to cause differences between family and non-family firms as well as among family firms with respect to the organizational goals pursued, risk taking, and investment horizon (Gómez-Mejía et al., 2007; Chrisman et al., 2012; Zellweger, 2007; Zellweger, Nason, and Nordqvist, 2012), all of which are important determinants of innovation activities. Family governance also often leads to idiosyncratic authority structures, incentives, and accountability norms (Carney, 2005; Gedajlovic et al., 2004; Gedajlovic and Carney, 2010) that can heavily influence innovation decision making and performance. Moreover, family governance can result in the development of unique resources (Habbershon and Williams, 1999) that may be leveraged in ways that influence the innovation processes and outcomes within family firms. 
A recent review article indicates that research about family firm innovation management is very much in its early stage and that, unsurprisingly, results are inconsistent (De Massis et al., 2013a). Furthermore, most of the work has been done by family business scholars while innovation management scholars have for the most part ignored the effects of the most ubiquitous form of firm governance, that by a family. This indicates an important gap in our knowledge about innovation management that needs to be addressed by more research at the intersection of the innovation management and family business fields of study.

This special issue aims to contribute to research at this intersection by presenting several cutting edge studies on the topic. Furthermore, this introduction presents a framework useful for organizing family involvement's influence on innovation management and for guiding future theoretical and empirical research on innovation management in family firms. The framework is based on two drivers of family governance - ability (discretion to act) and willingness (disposition to act) - and the paradox that they cause in family firms as they attempt to manage the innovation process.

The article is organized as follows. The next section introduces the ability versus willingness paradox. Then the framework is used to interpret innovation management in family firms. Finally, we summarize the papers in this special issue, outline implications for future research, and provide some conclusions.

\section{The Ability and Willingness Paradox in Family Firm Innovation Management}

Technological innovation is the process by which entrepreneurs exploit opportunities to commercialize new products, services, processes, or business models (Drucker, 1986). ${ }^{1} \mathrm{It}$ is managed within the firm through the inputs and processes which together produce the outputs. Internal to the firm, the inputs and processes are in turn driven by the goals, intentions, motivations, resources, power, and legitimacy of the firm's dominant coalition.

\footnotetext{
${ }^{1}$ In the rest of the article, we will use the shorter term "innovation" although our discussions refer mainly to technological innovation.
} 
Our framework is concerned with drivers of the inputs and processes, specifically the willingness and ability of family firms to innovate.

Ability and willingness are two key drivers of family governance that theoretically cause the differences in behavior and performance between family and non-family firms as well as among family firms. By ability we mean the family owners' discretion to direct, allocate, add to, or dispose of a firm's resources (De Massis et al., 2014). It includes latitude in selecting the goals of the organization and in choosing among a range of feasible strategic, structural, and tactical options (Hambrick and Finkelstein 1987; Morck, Shleifer, and Vishny 1988). Owners' discretion arises from their power and legitimacy as defined by the prevailing cultural, political, regulatory, competitive, and capital market conditions that influence property rights. As a consequence, family firms are thought to have unusual ability to behave idiosyncratically because, by definition, family members hold controlling ownership in the firm and typically are dominant members of the top management team and/or board of directors (e.g., Carney, 2005; Chrisman et al., 2012).

By contrast, willingness is defined as the disposition of the family owners to engage in idiosyncratic behavior based on the goals, intentions, and motivations that drive the owners to influence the firm's behavior in directions diverging from those of non-family firms or the institutional norms among family firms. For example, research has shown that family owners gain socioemotional wealth or affective value through their ownership and involvement in a firm, and that the extent to which such non-economic utilities influence their decisions is a primary cause of the differences between family and non-family firms (e.g., Gómez-Mejia et al., 2007).

Interestingly, while some management theories assume that ability is usually accompanied by willingness, this is not always the case (Chrisman et al., 2012; De Massis et al., 2014). Furthermore, both the socioemotional and economic foundations of willingness 
can vary considerably from family firm to family firm (Berrone et al., 2012). Consequently, the willingness and ability propensities of family firms with respect to innovation may be more heterogeneous than those of non-family firms.

Innovation can be a powerful strategic tool to acquire, nurture and maintain competitive advantage (Porter, 1990; Kleinschmidt and Cooper, 1991). However, it also entails significant risk, requires a strong commitment of resources, and takes time to produce tangible outcomes. Moreover, it can lead managers to operate in domains where results are difficult to predict and the need for external financial and human resources is necessarily greater. Because of these characteristics of innovation, family firms are considered to be less willing to innovate than nonfamily firms. Reasons cited for this unwillingness include risk aversion, lack of the requisite skills within the family and hesitancy to share control with nonfamily managers who have such skills (Garcia and Calantone, 2003; McDermott and Colarelli O'Connor, 2002), commitment to traditional product lines, and a desire to minimize the need for external financing. On the other hand, family firms also have greater discretion because of personalized control, low levels of formalization and bureaucracy, long term investment horizons, patient capital, altruism, and interest alignment between owners and managers (Carney, 2005; Schulze et al., 2001; Sirmon and Hitt, 2003). The greater discretion that family owners are believed to have in combination with family firms' unwillingness to innovate thus constitutes a paradox, by which we mean they have contrary elements that are interrelated, concurrent, and durable (Smith and Lewis, 2011).

In most instances the paradox is manifested by family firms innovating less despite having the ability to do more. But the paradox is sometimes complicated by the fact that ability and willingness vary in type and amount among different family firms, both of which make the outcome of their interaction more heterogeneous and difficult to predict. This is partially a function of controllability and capability since willingness to behave 
idiosyncratically is dependent upon the perceived feasibility and efficacy of such actions. Thus, the tendency among family firms to innovate or not is dependent upon the amount of ownership held by the family and their level of involvement in firm governance. It is also partially a function of the sources of willingness since family firms have a variety of economic and non-economic goals that can lead to substantially different behaviors. For example, while control is of paramount concern for most family firms the trade-off between concerns for current control and future control can lead to substantially different propensities to innovate (e.g., Chrisman and Patel, 2012). Furthermore, individually and in combination, the relative importance of control, survival, profitability, intra-family succession, identity (and reputation), emotional attachment, and social ties (e.g., Berrone et al., 2012) may lead to different amounts and types of innovation activities. Finally, the paradox is partially a function of situational factors. Performance aspirations, environmental jolts, generational transfers, and a variety of yet-to-be studied factors can cause variations in innovation activities among family firms and preference reversals with a particular family firm over time that are often more extreme than those experienced by non-family firms.

The literature provides several examples of the ability and willingness paradox in family firms. Regarding key inputs of the innovation process, the theoretical and empirical literature is generally consistent in pointing to a negative relationship between family governance and investments in R\&D (e.g., Block, 2012; Chen and Hsu, 2009; Munari et al., 2010). In one of the most recent contributions, Chrisman and Patel (2012) show that although family owners have the power and legitimacy to commit a superior level of resources to R\&D in comparison with nonfamily firms, most do not do so and whether they do or not depends on willingness. Chrisman and Patel (2012) identify transgenerational succession intentions and performance aspirations gaps as two drivers of the ability and willingness paradox. Interestingly, transgenerational succession intentions and below-aspiration level performance 
are both associated with higher R\&D investments in family firms than non-family firms whereas concern for current control and performance that exceeds aspirations both result in lower investments for family firms compared to non-family firms. Chrisman and Patel (2012) use the behavioral agency model and myopic loss aversion concept to explain these results.

With regard to how innovation activities are conducted, further paradoxes are visible. For instance, in their attempt to preserve control over innovation, family firms do not have the same inclination to engage in open innovation in comparison with nonfamily firms (Chesbrough, 2003; Kotlar et al., 2013). This occurs even though they are thought to have superior ability in identifying opportunities and acquiring knowledge from outside their boundaries because of their non-economic goals, long-term orientation, and ties with external stakeholders (Miller and Le Breton-Miller, 2005; Patel and Fiet, 2011).

Concerning the outputs of innovation, research has devoted substantial efforts to studying the response of incumbent firms to discontinuous technological change and the consequent performance implications (Hill and Rothaermel, 2003). Recent research has shown that family governance creates a paradox when the organization is confronted with the choice of whether and when to adopt a discontinuous technology. König et al. (2013) suggest that while family governance results in family firms adopting discontinuous technology later than nonfamily firms, when they do decide to adopt it, they implement this decision more rapidly.

As summarized in Table 1, the articles included in this special issue can be interpreted in light of the ability and willingness paradox. For example, Matzler et al.'s (2014) study of firms listed on the Frankfurt stock exchange finds that family management and governance is negatively related to innovation inputs yet positively related to innovation outputs. Similarly, Kraiczy et al.'s (2014) study of another sample of German family firms shows that the positive influence of the risk-taking propensity of the CEO on firm innovation declines as the 
ownership held by members of the top management team increases, especially as the firm ages. Their results suggest that the ability and willingness paradox grows larger as the family moves into later generations and as power is shared among a larger number of family members. Interestingly, Sciascia et al.'s (2014) analysis of a sample of small and mediumsize firms from Italy suggests that the long term orientation of family firms increases their ability to invest in R\&D but not their willingness. The apparent contradiction between their results and other studies may be resolved by their finding that reluctance to invest is less severe when the financial wealth of the family is not held hostage to the fate of a single firm. Kammerlander et al.'s (2014) article shows that willingness exhibited through the noneconomic goal pursued engenders a variety of responses to discontinuous technological changes among family firms. Chrisman et al. (2014) contribute further to a better understanding of family firm heterogeneity and the ability and willingness paradox with regard to innovation by pointing out that the family's relative emphasis on command, continuity, connections, and community (Miller and Le Breton-Miller, 2005) will lead to a complex pattern of behaviors that may not always be a linear function of ability, as measured through ownership or control.

\section{TABLES 1 and 2 ABOUT HERE}

\section{Questions for Future Research}

Ability and willingness, and the paradoxes engendered by their interaction provide a means to highlight a number of areas for further research that extend the work of the papers presented in this special issue. Table 2 summarizes three broad areas for future research. First, as noted above, not all family firms are the same. Heterogeneity of family firms in terms of their ownership, governance, objectives, resources, etc. may have implications for the paradox (Chua, Chrisman, Steier, and Rau, 2012; Westhead and Howorth, 2007). Different governance configurations in terms of, for example, board composition, family 
involvement in management, and business groups, combined with different types and amounts of diversification and internationalization may influence the firm's ability to implement innovation strategies and its willingness to engage in different types of innovation. For example, Patel and Chrisman (2014) find that family firms are more likely to engage in innovative activities that provide more reliable performance rather than higher performance (except when performance is below aspiration levels), but it is yet to be determined if this applies under all possible combinations of family goals, governance, and resources.

There is also a need to understand what factors moderate the relationship between family governance and the ability and willingness to innovate. For example, while we know that board composition and the use of subsidiary structures are closely related to the survival of family firms (Wilson, Wright and Scholes, 2013), the link between these factors and innovation have not been explored. Some family firms may not suffer from the paradox, or may do so only for particular aspects but at present insights are lacking. Further, we lack insights into how family firms resolve the paradox in the way they conduct different aspects of the innovation process. For example, future analysis could usefully explore differences between family firms in how and to what extent they develop radical innovations, foster creativity, adopt innovations from other organizations or from within other parts of the family firm, finance innovation projects, and organize innovation programs. Moreover, two simple questions have not been adequately addressed in the literature: (1) if family firms prefer not to innovate why do they do so at all, and (2) if innovation is important for firm performance how are family firms able to survive, particularly in environments where family governance is not needed to protect property rights?

Second, the paradox may evolve over time. For instance, the disruption accompanying succession may change firm goals, board composition, and management and this may in turn change the balance between ability and willingness to innovate. For example, Kotlar and De 
Massis (2013) emphasize the role of intra-family succession as a catalyst of change and find that the imminence of an intra-family succession appears to disrupt goal diversity in family firms. Likewise, Voordeckers et al (2007) and Bammens et al. (2008) show that succession induces changes in family firms' board composition. The consequences of these changes for the paradox and for innovation activities need to be explored. Similarly, the success or failure of prior innovation activities may lead to learning and changes in behavioral propensities which may increase or decrease the paradox between ability and willingness at any stage of the innovation process, as well as change the relationships between innovation inputs, activities, outputs, and firm performance. Yet we have few insights into this learning process. Finally, the paradox may differ among diverse populations of family and non-family firms that are otherwise similar in other respects. For example, the paradox that distinguishes family and non-family firms may be stronger or weaker among widely-held corporations, cooperative ventures, private companies, joint ventures, venture capital-backed firms or stateowned firms. The paradox may also take on dissimilar forms and significance in different countries with different legal systems and stages of economic development.

\section{Conclusion}

With regard to innovation, given similar resources, a rational theory of firm behavior would suggest that owing to its importance, family and non-family firms would engage in similar levels of innovation, achieve similar levels of success, and register similar levels of performance. Empirical evidence has shown this not to be the case. Consequently, a theory has been emerging to suggest that family firms, owing to the virtually unfettered discretion of family owners and the involvement of family managers have superior ability to innovate compared to their non-family competitors. However, that theory also specifies that owing to their unique set of economic and non-economic goals, family owners are often willing to engage in idiosyncratic strategies, which in many cases means they innovate less rather than 
more. This causes a paradox because rational models of firm behavior do not always apply to family firms. Furthermore, given the aversion to innovate among many family firms, it is natural to wonder why they innovate at all and, given the importance of innovation, why they continue to survive. In this article we have introduced this paradox and explained some of its interesting features. We have also briefly outlined the articles contained in this special issue and proposed some directions that future research on family firm innovation could take. Given the many contingencies that might affect innovation in family firms, we have only started to scratch the surface of the issues that need to be investigated. Nevertheless, we will consider our efforts to be successful if we have encouraged other scholars to tackle some of the interesting research questions that an application of the ability and willingness paradox to studies of family firm innovation suggests. 


\section{References}

Bammens Y., Voordeckers W., and Van Gils A. (2008). Boards of directors in family firms: a generational perspective. Small Business Economics, 31, 163-180.

Berrone, P., Cruz, C., and Gómez-Mejia, L.R. (2012). Socioemotional wealth in family firms: Theoretical dimensions, assessment approaches, and agenda for future research. Family Business Review, 25, 258-279.

Block, J. H. (2012). R\&D investments in family and founder firms: An agency perspective. Journal of Business Venturing, 27, 248-265.

Carney, M. (2005). Corporate governance and competitive advantage in family-controlled firms. Entrepreneurship Theory and Practice, 29, 249-265

Chen, H. L., and Hsu, W. T. (2009). Family ownership, board independence, and R\&D investment. Family Business Review, 22, 347-362.

Chesbrough, H. (2003). Open Innovation: The New Imperative for Creating and Profiting from Technology. Boston: Harvard Business School Press.

Chrisman, J. J., Chua, J., Pearson, A. and Barnett, T. (2012). Family involvement, family influence, and family centered non economic goals in small firms. Entrepreneurship Theory and Practice 36, 267-293.

Chrisman, J. J. and Patel, P. J. (2012). Variations in R\&D investments of family and nonfamily firms: Behavioral agency and myopic loss aversion perspectives. Academy of Management Journal, 55, 976-997.

Chrisman, J.J., Fang, H., Kotlar, J., and De Massis, A. (2014). A note on family influence and the adoption of discontinuous technologies in family firms. Journal of Product Innovation Management (this issue).

Chua, J.H., Chrisman, J.J., Steier, L.P., and Rau, S.B. (2012). Sources of heterogeneity in family firms: An introduction. Entrepreneurship Theory and Practice, 36, 1103-1113.

De Massis A., Frattini F. and Lichtenthaler U. (2013a). Research on technological innovation in family firms: Present debates and future directions. Family Business Review, 26(1), 10-31.

De Massis A., Frattini F., Pizzurno E. and Cassia L. (2013b). Product innovation in family versus non-family firms: An exploratory analysis. Journal of Small Business Management. DOI: $10.1111 / \mathrm{jsbm} .12068$.

De Massis A., Kotlar J., Chua J.H. and Chrisman J.J. (2014). Ability and willingness as sufficiency conditions for family-oriented particularistic behavior: Implications for theory and empirical studies. Journal of Small Business Management, 52(2), 344-364.

Drucker, P. (1986). Innovation and Entrepreneurship: practice and principles, Harper \& Row. 
Garcia, R. and Calantone, R. (2003). A critical look at technological innovation typology and innovativeness terminology: a literature review. Journal of Product Innovation Management, 19, 110-132.

Gedajlovic, E., and Carney, M. (2010). Markets, hierarchies, and families: Toward a transaction cost theory of the family firm. Entrepreneurship Theory and Practice, 34, 1145 1172 .

Gedajlovic, E., Lubatkin, M. H., and Schulze, W. S. (2004). Crossing the threshold from founder management to professional management: A governance perspective. Journal of Management Studies, 41, 899-912.

Gómez-Mejía, L. R., Haynes, K. T., Núñez-Nickel, M., Jacobson, K. J. L., and MoyanoFuentes, J. (2007). Socioemotional wealth and business risks in family-controlled firms: Evidence from Spanish olive oil mills. Administrative Science Quarterly, 52, 106-137

Habbershon, T. G., and Williams, M. (1999). A resource-based framework for assessing the strategic advantages of family firms. Family Business Review, 9, 157-170

Hambrick, D. C., and Finkelstein, S. (1987). Managerial discretion: A bridge between polar views of organizational outcomes. Research in Organizational Behavior 9, 369-406.

Hill, C.W., and Rothaermel, F.T. (2003). The performance of incumbent firms in the face of radical technological innovation. Academy of Management Review, 28: 257-274.

Kammerlander, N., and Ganter, M. (2014). An attention-based view of family firm adaptation to discontinuous technological change: Exploring the role of family CEOs' non-economic goals. Journal of Product Innovation Management (this issue)

Kellermanns, F.W., Eddleston, K., Sarathy, R. and Murphy, F. (2012). Innovativeness in family firms: A family influence perspective. Small Business Economics, 38(1): 85-101.

Kleinschmidt, E.J. and Cooper, R.G. (1991). The impact of product innovativeness on performance. Journal of Product Innovation Management, 8, 240-251.

König, A., Kammerlander, N., and Enders, A. (2013). The family innovator's dilemma: How family influence affects the adoption of discontinuous technologies by incumbent firms. Academy of Management Review, 38, 418-441.

Kotlar J. and De Massis A. (2013). Goal setting in family firms: Goal diversity, social interactions, and collective commitment to family-centered goals. Entrepreneurship Theory \& Practice, 37, 1263-1288.

Kotlar, J., De Massis, A., Frattini, F., Bianchi, M., and Fang, H. (2013). Technology acquisition in family and non-family firms: A longitudinal analysis of Spanish manufacturing firms. Journal of Product Innovation Management, 30, 1073-1088

Kraiczy, N.D., Hack, A., and Kellermanns, F.W. (2014). How does CEO risk-taking propensity affect new product portfolio innovativeness in small and medium-szied family firms? Journal of Product Innovation Management (this issue). 
La Porta, R., Lopez-de-Silanes F., Shleifer A., and Vishny R. (1999). Corporate ownership around the world. Journal of Finance 54, 471-517.

Matzler, K., Veider, V., Hautz, J., and Stadler, C. (2014). How do family ownership, management and governance impact innovation input and output? Journal of Product Innovation Management (this issue).

McDermott, C.M. and Colarelli O'Connor, G. (2002). Managing radical innovation: an overview of emergent strategy issues. Journal of Product Innovation Management, 19, 424438.

Miller, D., and Le Breton-Miller, I. (2005). Managing for the long run. Boston, MA: Harvard Business School.

Morck, R., Shleifer, A. and Vishny, R.W. (1988). Management ownership and market valuation: An empirical analysis, Journal of Financial Economics 20, 293-315

Munari, F., Oriani, R., and Sobrero, M. (2010). The effects of owner identity and external governance systems on R\&D investments: A study of Western European firms. Research Policy, 39, 1093-1104.

Patel, P. C. and Chrisman, J. J. (2014). Risk abatement as a strategy for R\&D investments in family firms. Strategic Management Journal, 35, 617-627.

Patel, P.C. and Fiet, J.O. (2011). Knowledge combination and the potential advantages of family firms in searching for opportunities. Entrepreneurship Theory and Practice, 35, 11791197.

Porter, M. (1990). The competitive advantage of nations. Harvard Business Review, 68(2), 73-93.

Schulze, W.S., Lubatkin, M.H., Dino, R.N., and Buchholtz, A.K. (2001). Agency relationships in family firms: Theory and evidence. Organization Science, 12, 99-116.

Sciacia, S. Nordqvist, M., Mazzola, P., and De Massis, A. (2014). How does family ownership affect R\&D intensity in SMEs and what is the role of the overlap between family wealth and firm equity? Journal of Product Innovation Management (this issue).

Sirmon, D.G., and Hitt, M.A. (2003). Managing resources: Linking unique resources, management, and wealth creation in family firms. Entrepreneurship Theory and Practice, 27, 339-358.

Smith, W. K., and Lewis, M. W. (2011). Toward a theory of paradox: A dynamic equilibrium model of organizing. Academy of Management Review, 36, 381-403.

Villalonga, B., and Amit, R. (2009). How are U.S. family firms controlled? Review of Financial Studies 22, 3047-3091. 
Voordeckers, W., Van Gils, A. and Van den Heuvel, J. (2007). Board composition in small and medium-sized family firms. Journal of Small Business Management, 45, 137-156.

Westhead, P., and Howorth, C. (2007). Types of private family firms: An exploratory conceptual and empirical analysis. Entrepreneurship \& Regional Development, 19, 405-431.

Wilson, N., Wright, M., and Scholes, L. (2013). Family business survival and the role of boards. Entrepreneurship Theory \& Practice, 37, 1369-1389.

Zellweger, T. (2007). Time horizon, costs of equity capital, and generic investment strategies of firms. Family Business Review, 20, 1-15.

Zellweger, T., Nason, R., and Nordqvist, M. (2012). From longevity of firms to transgenerational entrepreneurship of families: Introducing family entrepreneurial orientation. Family Business Review, 25, 136-155. 
Table 1: Summary of the Special Issue Articles

\begin{tabular}{|c|c|c|c|c|c|}
\hline Authors & Research Questions & Theories used & $\begin{array}{l}\text { Data and } \\
\text { method }\end{array}$ & Findings & Paradox \\
\hline $\begin{array}{l}\text { Matzler, } \\
\text { Veider, Hautz } \\
\text { and Stadler }\end{array}$ & $\begin{array}{l}\text { How do family ownership, } \\
\text { management and } \\
\text { governance impact } \\
\text { innovation inputs and } \\
\text { outputs? }\end{array}$ & $\begin{array}{l}\text { Resource- } \\
\text { Based View, } \\
\text { Agency } \\
\text { Theory }\end{array}$ & $\begin{array}{l}134 \text { German } \\
\text { public traded } \\
\text { family and } \\
\text { nonfamily } \\
\text { firms, } \\
\text { Quantitative } \\
\text { analysis }\end{array}$ & $\begin{array}{l}\text { There is a negative impact of } \\
\text { family management and } \\
\text { governance on R\&D intensity } \\
\text { (innovation input) but a positive } \\
\text { impact of family management on } \\
\text { number of patents and forward } \\
\text { citations intensity (innovation } \\
\text { outputs) and of family } \\
\text { governance on number of } \\
\text { patents. Familial TMTs are more } \\
\text { efficient in exploiting given } \\
\text { R\&D investments, as they are } \\
\text { more likely to engage in social } \\
\text { capital-building unique to family } \\
\text { firms. }\end{array}$ & $\begin{array}{l}\text { Family involvement in } \\
\text { management and governance } \\
\text { reduces a firm's propensity } \\
\text { toward R\&D investments, but } \\
\text { increases the firm's ability to take } \\
\text { the most out of them, through a } \\
\text { more successful deployment of } \\
\text { idiosyncratic resources. The key } \\
\text { managerial challenge is to identify } \\
\text { the mechanism that increase } \\
\text { family firms' willingness to } \\
\text { devote resources to R\&D and } \\
\text { technological development, more } \\
\text { than increasing their ability to } \\
\text { turn them into innovation output. }\end{array}$ \\
\hline $\begin{array}{l}\text { Kraiczy, Hack } \\
\text { and } \\
\text { Kellermanns }\end{array}$ & $\begin{array}{l}\text { How does CEO risk-taking } \\
\text { propensity affect new } \\
\text { product portfolio } \\
\text { innovativeness in small and } \\
\text { medium-sized family } \\
\text { firms? }\end{array}$ & $\begin{array}{l}\text { Socio- } \\
\text { emotional } \\
\text { Wealth } \\
\text { Theory, Upper } \\
\text { Echelon } \\
\text { Theory }\end{array}$ & $\begin{array}{l}114 \text { German } \\
\text { family firms } \\
\text { in } \\
\text { manufacturing } \\
\text { industries, } \\
\text { Quantitative } \\
\text { analysis }\end{array}$ & $\begin{array}{l}\text { CEO risk-taking propensity has a } \\
\text { positive effect on new product } \\
\text { portfolio innovativeness. The } \\
\text { organizational context of family } \\
\text { firms moderates the impact of } \\
\text { CEO risk-taking propensity on } \\
\text { new product portfolio } \\
\text { innovativeness. The relationship } \\
\text { between CEO risk-taking } \\
\text { propensity and new product } \\
\text { portfolio innovativeness is } \\
\text { weaker if levels of ownership by } \\
\text { Top Management Team family } \\
\text { members are high (high SEW). } \\
\text { The effect of CEO risk-taking }\end{array}$ & $\begin{array}{l}\text { Family firms' CEOs have } \\
\text { discretion to influence the } \\
\text { strategic behavior of their } \\
\text { organization and increase } \\
\text { innovativeness of the new product } \\
\text { portfolio. The higher their risk- } \\
\text { propensity, the stronger will be } \\
\text { their willingness to increase } \\
\text { innovativeness. This is not the } \\
\text { case with family firms with high } \\
\text { levels of ownership by Top } \\
\text { Management Team members, } \\
\text { creating a paradoxical situation. } \\
\text { Time is important in resolving the } \\
\text { paradox as the closer a family }\end{array}$ \\
\hline
\end{tabular}




\begin{tabular}{|c|c|c|c|c|c|}
\hline & & & & $\begin{array}{l}\text { propensity on new product } \\
\text { portfolio innovativeness is } \\
\text { stronger in family firms at earlier } \\
\text { generational stages (high SEW). }\end{array}$ & $\begin{array}{l}\text { firm is to the founding generation, } \\
\text { the lower the reduction of the } \\
\text { CEO's disposition to increase the } \\
\text { innovativeness of the new product } \\
\text { portfolio in case of high levels of } \\
\text { TMT ownership. }\end{array}$ \\
\hline $\begin{array}{l}\text { Sciacia, } \\
\text { Nordqvist, } \\
\text { Mazzola and } \\
\text { De Massis }\end{array}$ & $\begin{array}{l}\text { How does family } \\
\text { ownership affect R\&D } \\
\text { intensity in SMEs and what } \\
\text { is the role of the overlap } \\
\text { between family wealth and } \\
\text { firm equity? }\end{array}$ & $\begin{array}{l}\text { Behavioral } \\
\text { agency model, } \\
\text { Socio- } \\
\text { Emotional } \\
\text { Wealth (SEW) } \\
\text { perspective }\end{array}$ & $\begin{array}{l}240 \text { privately } \\
\text { held SMEs } \\
\text { based in Italy, } \\
\text { Quantitative } \\
\text { analysis }\end{array}$ & $\begin{array}{l}\text { In SMEs where there is a high } \\
\text { overlap between family wealth } \\
\text { and firm equity the relationship } \\
\text { between family ownership and } \\
\text { R\&D intensity is negative due to } \\
\text { family owners' greater desire to } \\
\text { protect SEW. If the overlap } \\
\text { between family's total wealth } \\
\text { and single firm equity is low the } \\
\text { relationship between family } \\
\text { ownership and R\&D intensity is } \\
\text { positive, as the low overlap } \\
\text { reduces the family's loss } \\
\text { aversion propensity, fostering } \\
\text { R\&D intensity. }\end{array}$ & $\begin{array}{l}\text { Family firms are less willing to } \\
\text { invest in innovation due to their } \\
\text { propensity to protect SEW. At the } \\
\text { same time, they are more able } \\
\text { than non-family firms to invest in } \\
\text { innovation due to their long-term } \\
\text { orientation. The extent of overlap } \\
\text { between family's total wealth and } \\
\text { single firm equity helps resolve } \\
\text { this paradox. }\end{array}$ \\
\hline $\begin{array}{l}\text { Kammerlander } \\
\text { and Ganter }\end{array}$ & $\begin{array}{l}\text { (1) How does the family } \\
\text { CEO's attention to non- } \\
\text { economic goals affect his } \\
\text { or her sense-making } \\
\text { process and, subsequently, } \\
\text { organizational adaptation to } \\
\text { discontinuous } \\
\text { technologies? and (2) How } \\
\text { and why does } \\
\text { heterogeneity in family } \\
\text { CEOs' non-economic goals } \\
\text { lead to heterogeneity in the } \\
\text { respective family firms' }\end{array}$ & $\begin{array}{l}\text { Attention- } \\
\text { Based View, } \\
\text { Sense-making } \\
\text { Theory }\end{array}$ & $\begin{array}{l}7 \text { German } \\
\text { family firms } \\
\text { in the } \\
\text { consumer } \\
\text { goods } \\
\text { industry, } \\
\text { Multiple case } \\
\text { study. }\end{array}$ & $\begin{array}{l}\text { The family CEO's specific non- } \\
\text { economic goals determine } \\
\text { whether the CEO assesses a } \\
\text { discontinuous technology as } \\
\text { relevant enough to warrant a } \\
\text { reaction from the firm and } \\
\text { constrain the set of considered } \\
\text { responses. The outcome of this } \\
\text { sense-making process determines } \\
\text { the organization's response. } \\
\text { Over time, family CEOs might } \\
\text { re-evaluate the emerging trend } \\
\text { based on their goals and adapt }\end{array}$ & $\begin{array}{l}\text { Although family CEOs have } \\
\text { discretion to commit firm } \\
\text { resources toward timely } \\
\text { responding to discontinuous } \\
\text { technologies, they do not have the } \\
\text { propensity to do so if their goal } \\
\text { setting process is strongly affected } \\
\text { by emotions. This paradoxical } \\
\text { situation does not happen when } \\
\text { other non-economic goals such as } \\
\text { power for control and trans- } \\
\text { generational value transfer are key } \\
\text { for the CEO. Time is an important }\end{array}$ \\
\hline
\end{tabular}




\begin{tabular}{|c|c|c|c|c|c|}
\hline & $\begin{array}{l}\text { adaptations to } \\
\text { discontinuous } \\
\text { technological change? }\end{array}$ & & & $\begin{array}{l}\text { organizational moves } \\
\text { accordingly. }\end{array}$ & $\begin{array}{l}\text { mechanism for resolving this } \\
\text { paradox, as non-economic goals } \\
\text { are likely to be aligned with } \\
\text { economic goals in the later phases } \\
\text { of the technology. }\end{array}$ \\
\hline $\begin{array}{l}\text { Chrisman, } \\
\text { Fang, Kotlar } \\
\text { and De Massis }\end{array}$ & $\begin{array}{l}\text { How do heterogeneity } \\
\text { aspects of family influence } \\
\text { affect the adoption of } \\
\text { discontinuous technologies } \\
\text { in family firms? }\end{array}$ & $\begin{array}{l}4 \text { Cs model of } \\
\text { command, } \\
\text { continuity, } \\
\text { community, } \\
\text { and } \\
\text { connections, } \\
\text { Organizational } \\
\text { goals and } \\
\text { preference } \\
\text { reversals }\end{array}$ & $\begin{array}{l}\text { This is a } \\
\text { conceptual } \\
\text { note }\end{array}$ & $\begin{array}{l}\text { The critical assumption in } \\
\text { König, et al. (2013) that family } \\
\text { influence differs only in degree } \\
\text { rather than kind is challenged. } \\
\text { This extends the König et al. } \\
\text { model by explaining how } \\
\text { heterogeneity in the family's } \\
\text { relative emphasis on command, } \\
\text { continuity, community, and } \\
\text { connections requires that the } \\
\text { multi-faceted and potentially } \\
\text { non-linear nature of family } \\
\text { influence be considered when } \\
\text { analyzing strategic decisions } \\
\text { concerning family firm } \\
\text { innovation. Five propositions for } \\
\text { future research are developed on } \\
\text { the effect of the 4Cs on the } \\
\text { adoption of discontinuous } \\
\text { technologies in family firms. }\end{array}$ & $\begin{array}{l}\text { Assuming that how much a family } \\
\text { is able to influence firm behavior } \\
\text { is determined solely and linearly } \\
\text { by the degree of family } \\
\text { involvement is reasonable. } \\
\text { However, to assume that how that } \\
\text { influence is exercised can be } \\
\text { captured by a single, linear } \\
\text { construct is problematic since } \\
\text { how family influence translates } \\
\text { into firm behavior varies in type } \\
\text { as well as degree according to key } \\
\text { family stakeholders goals and } \\
\text { their willingness to use their } \\
\text { power to govern the firm in a } \\
\text { particularistic way. }\end{array}$ \\
\hline
\end{tabular}


Table 2: Some Future Research Questions

\begin{tabular}{|c|c|c|c|c|}
\hline Factors & Family governance & Willingness/Ability & Paradox & $\begin{array}{l}\text { Innovation Inputs - } \\
\text { Activities - Outputs }\end{array}$ \\
\hline $\begin{array}{c}\text { Heterogeneity } \\
\text { of Family } \\
\text { Firms }\end{array}$ & $\begin{array}{l}\text { How do family firms differ in } \\
\text { terms of their ownership, } \\
\text { board, management and legal } \\
\text { (group) configurations, goals, } \\
\text { structures and processes? To } \\
\text { what extent are these } \\
\text { differences the result of } \\
\text { innovation activity or its } \\
\text { facilitator? }\end{array}$ & $\begin{array}{l}\text { How does the balance between } \\
\text { ability and willingness vary } \\
\text { between these different types of } \\
\text { family firms? How do family firms } \\
\text { differ in their human, social and } \\
\text { financial resources/capabilities for } \\
\text { innovation? How do they differ in } \\
\text { the extent to which they access } \\
\text { these resources/capabilities? }\end{array}$ & $\begin{array}{l}\text { Which types of family firms } \\
\text { experience greater, lesser or } \\
\text { no paradox? To what extent } \\
\text { does the paradox differ } \\
\text { between family firms across } \\
\text { and within different } \\
\text { industrial sectors, different } \\
\text { institutional contexts, and } \\
\text { different spatial contexts? }\end{array}$ & $\begin{array}{l}\text { How do different types of } \\
\text { family firms resolve the } \\
\text { paradox in different aspects of } \\
\text { the innovation process? Who } \\
\text { takes the initiative in resolving } \\
\text { this paradox (the founder, the } \\
\text { board, the family council, } \\
\text { etc.)? }\end{array}$ \\
\hline Time & $\begin{array}{l}\text { How does family governance } \\
\text { change over time? How does } \\
\text { it change as a result of } \\
\text { learning and succession? } \\
\text { How does it change in } \\
\text { response to innovation or to } \\
\text { facilitate innovation? }\end{array}$ & $\begin{array}{l}\text { How do changes in family } \\
\text { governance over time influence } \\
\text { ability and willingness? To what } \\
\text { extent and why are these factors } \\
\text { addressed within generations or } \\
\text { following generational change? }\end{array}$ & $\begin{array}{l}\text { How do changes in ability } \\
\text { and willingness change the } \\
\text { paradox? Does the paradox } \\
\text { reduce as a result of } \\
\text { learning and succession? In } \\
\text { what ways, when and why? }\end{array}$ & $\begin{array}{l}\text { How do the consequences of } \\
\text { the changing paradox } \\
\text { moderate the relationships } \\
\text { between inputs, activities, and } \\
\text { outputs? To what extent and } \\
\text { where is there 'stickiness' in } \\
\text { the adaptation of the } \\
\text { innovation process? }\end{array}$ \\
\hline $\begin{array}{l}\text { Populations } \\
\text { of family and } \\
\text { non-family } \\
\text { firms }\end{array}$ & $\begin{array}{l}\text { How do family firms differ } \\
\text { from different types of non- } \\
\text { family firms in terms of } \\
\text { ownership, board and } \\
\text { management configurations, } \\
\text { goals, structures and } \\
\text { processes? How do they } \\
\text { differ in terms of different } \\
\text { approaches to innovation? }\end{array}$ & $\begin{array}{l}\text { How does the balance between } \\
\text { ability and willingness vary } \\
\text { between different family firms and } \\
\text { different types of non-family firm? } \\
\text { To what extent are such } \\
\text { differences influenced by the } \\
\text { sector and type of innovation? }\end{array}$ & $\begin{array}{l}\text { In what governance, } \\
\text { sectoral, and institutional } \\
\text { circumstances do family } \\
\text { firms experience greater, } \\
\text { lesser or no paradox } \\
\text { compared with different } \\
\text { types of non-family firm? }\end{array}$ & $\begin{array}{l}\text { How do family firms differ } \\
\text { from different types of non- } \\
\text { family firms in how they } \\
\text { resolve the paradox in different } \\
\text { aspects of the innovation } \\
\text { process? How do they differ } \\
\text { in terms of who takes the } \\
\text { initiative? }\end{array}$ \\
\hline
\end{tabular}

